Available online at www.refaad.com

Bull. adv. Engl. stud., 4(1)2020, 14-26

Research Article

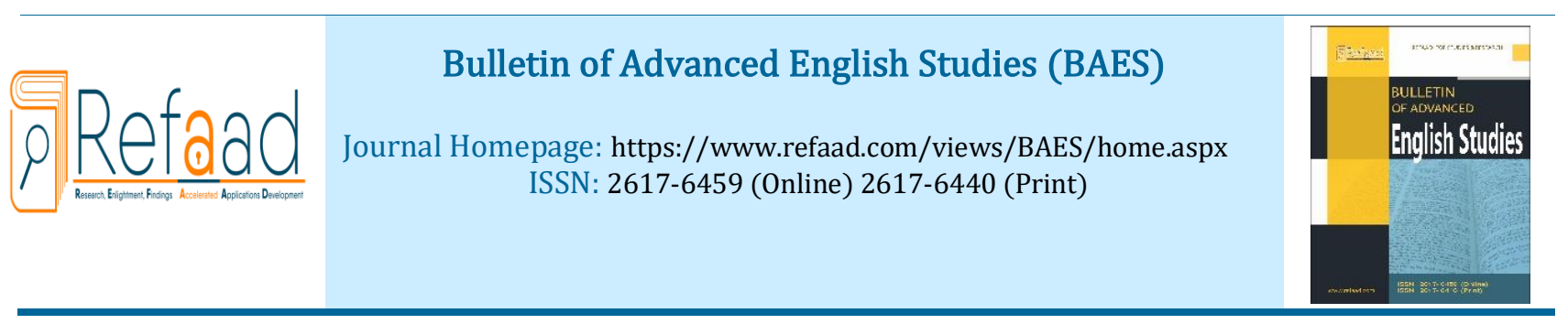

\title{
Ali Salem's The Phantoms of New Egypt (1968)1: A Subversive Reading of Post- Independence Dystopia
}

\section{Marwa Essam Eldin Fahmy Alkhayat ${ }^{\text {* }}$}

a Associate Professor of Comparative Literature \& Criticism, Faculty of Foreign Languages \& Translation English Department, Ahram Canadian University, Giza, Egypt

\begin{abstract}
The current study aims to establish Salem's The Phantoms of New Egypt ${ }^{2}$ as a dystopian drama to expose the collapse of utopia and the rise of dystopia within the national pitfalls of the ruling class in post-independence Egypt. This provides an explanation of the title of the present paper since dystopia has been perceived as an escape to dismal socio-political conditions while utopia has been considered as an escape from a grim historical reality to an ideal hypothetical one. Moreover, the present study examines the close relationship between dystopian drama and dark satire since each of them is a counterpoint to the vision of utopia. Satire foregrounds the huge cleavage between a utopian dream and a dystopian bleak reality to underscore acts of resistance and struggle. Salem's The Phantoms of New Egypt is as a perfect example of the 'totalitarian laughter' which is a prominent feature in Bakhtin's notion of 'grotesque realism'. This highlights post-independence grotesque power which is both incongruous and monstrous. Power abuse is also scrutinized fantastically within Foucault's 'panoptic gaze' 3 to create normalized and docile subjects.
\end{abstract}

Keywords: Dystopian Drama; Grotesque Laughter; Dark Satire; Egyptian Theatre.

Introduction: The Dramatist-Activist Political Satire:

Salem's view of realism is stated in his famous play, The Buffet(1967) through the character of Writer:

I don't reproduce it [reality] as it is. I'm not a photographer. I do something completely different. I take our life

apart and then I put it back together according to my taste, in my own way. It comes out as something else, something completely different. However, if we observe it closely, we find that it's exactly like it ... this is what I do.

The Phantoms of New Egypt can be labeled a political play, or to put it more accurately, a play that becomes only meaningful if it is read in a political light. Thus, Eagleton's exhortation in his Literary Theory (1989) is especially meaningful to this play: "You simply have to argue about politics. It is not a question of debating whether, 'literature' should be, related to 'history' or not; it is a question of different readings of history" (p. 209). Postindependence Egypt is transfigured from a utopia into a dystopia because of the political class's harsh ruling policies which have proved to be pointless and inhuman as well.

The performance of The Phantoms of New Egypt was banned after one week because of its severe political implications. It appeared after the performance of an earlier play, The Man Who Fooled the Angels, which poked fun at Nasser's regime. This explains the scarce references and articles since no Egyptian critic could dare to write a word at that time, especially after witnessing the police official measures to close or in particular to seal off the theatre, Al-Corsal. In general, Egyptian critics such as Nadia Farag-Badawi and Shukry Ayyad classify Salem's plays

\footnotetext{
${ }^{*}$ Corresponding author

Email address: drmarwaalkhayat@gmail.com (Marwa Essam Eldin Alkhayat)

DOI: https://doi.org/10.31559/baes2020.4.1.3

Received Date: 28/12/2019

Accepted Date: 16/2/2020
} 
into two categories: the real and the fantasy plays. However, their studies lack the analysis of the essential qualities of the literature of the fantastic, a gap which this study attempts to fill in.

On the linguistic level, 'fantastic' appears simply to refer to the adjectival version of the noun fantasy. Yet, Tzvetan Todorov relates the fantastic to a category which he calls "the uncanny" $(1975, \mathrm{p} .46)$. He states that "the uncanny" is primarily associated with supernatural devices: "events which may be reality accounted for by the laws of reason, but which are, in one way or another incredible, extraordinary, shocking, singular, disturbing or unexpected"(1975, p. 46). This is different from "the marvelous" which is an echo of fantasy and "appears a good deal more difficult to define" (Armitt, p. 30) since it is categorized as "hyperbolic marvelous, exotic marvelous, and scientific marvelous" (Armitt, p. 30). In Magical Realism: Theory, History, Community (1995), Lois Zamora and Wendy Faris agree that "magical realism is a mode suited to explore and transgress boundaries, whether the boundaries are ontological, political, geographical, or generic. Magical realism facilitates the fusion or coexistence of possible world, spaces"' (p. 5).

Thereby, the aim of the study is to capture the potentiality of magical realism in order to assault basic structures of rationalism and realism, thus, my endeavor centers on impossible or strange events to indict political indignation and to transgress existing inevitable ideological totalitarianism. Through my analysis, The Phantoms of New Egypt is interrogated within the paradigm of Bakhtin's theories of 'degrading humor' and the notion of 'grotesque realism' to highlight the features of 'totalitarian laughter' as theorized by Bakhtin to expose the unacceptable tactics of physical torture adopted by a ruthless police power.

\section{Heliopolis Police Station: A Spatial Signifier of a Repressive 'New Egypt':}

The Phantoms of New Egypt is a provocative dramatic text on account of its rich political implication. The hypothesis is that the play can be an outstanding example of what Foucault believes that one "fictions" a history starting from a political reality that renders it true, one "fictions" a politics that does not as yet exist starting from a historical truth. (1979, p. 74-5). In the Phantoms of New Egypt, I attempt to discover the "frames of reference" or the "ideological subtext" (p. 261), in Jameson's words. One of the most forceful "frames of reference" or dramatic signs in the play is that connected with place and when it is deciphered, it signifies the semantic depths of Salem's political message. "New Egypt" is both a title and a place which is Heliopolis Police Station, the dominant setting that gives vent to an ideological stand which is the disenchantment with post-revolution Egypt. Salem's purpose is to expose a turbulent post-independence Egypt.

"New Egypt" -as shown in the play's title- seemingly refers to Heliopolis, a refined and a classy district in Cairo. On the underlying level, Salem subtly refers to post-independence Egypt with all its ideals and lapses. "New" is ironically used to represent the two stages experienced by the Egyptians: the initial euphoria and enchantment with the newly-born regime and later its deterioration and failures. Heliopolis police station allegorizes the shift from bliss to nightmare stressing the state of dialogism which is meant to re-invoke ironically the ugly reality of "New Egypt".

The prefatory scene introduces the setting through non-verbal means. The setting is described as "elegant", "beautiful", "relaxing" and "quiet". Salem's stage directions exhibit a kind of the fantastic to suit the early utopist atmosphere of "New Egypt":

\section{Stage direction:}

The place is very elegant .... The lighting is quiet and relaxing, paintings decorate the wall, a series of iron chain hanging on the wall in a beautiful layout. This is not the ordinary iron-chain we know - it is made of colored plastic and it is used as ornaments ... The place is beautiful and elegant to the degree that we could not believe that it is a police station unless we read "the police is in the service of the citizens", the large illuminated placard hung against the wall. (Italics mine, The Phantoms of New Egypt, p. 9).

This setting is apt to introduce the concept of theatrical space in terms of the "mobility" of the sign to outline the nature or specificity of the theatre sign. "This consists of ", as De Toro comments, " the constant mutation theatre signs experience. This mutation has a close relationship with the icon/index/symbol" (p. 70). Thus, the dramaturgical reading of the "theatre object" includes both the text's structural articulation and ideological components.

To illustrate, within the theatrical space, the shapes which are deployed on stage exist in an iconic capacity and the setting as depicted by Salem undergoes a change which could explain the "constant mutation of theatre signs". In Heliopolis police station, the paintings, the colored-chain and the lighting - as signs- enjoy a tremendous degree of "transformability" and "mutability". They are constantly shifting from the iconic to the indexical to the symbolic. In Act One Scene One, the depicted theatre objects [the paintings, the colored-chain and the lighting, etc.] are indexical signs of a utopia where everything is full of glamour. As the plot progresses, these ideal police station shifts to the symbolic level and this generates the "symbolic space" which refers to political turmoil in post-independence Egypt, a condition delineated within the fantastic realm. Thereby, the setting's "transformability" emphasizes the kinetic element inherent in the theatrical space so as to create a mood and in this particular setting, a grim one.

These idealistic police station brings to the fore the deployment of "the fantastic" that is described by Richard Mathews as being a "powerful, vivid mode of human consciousness" enabling man "to enter worlds of an infinite 
possibility [via] imagination" (p. 1). It is " a type of fiction", as Mathews continues, " that evokes wonder mystery or magic - a sense of possibility beyond the ordinary material, rationally predictable world in which we live" (p. 1). Salem consciously breaks away from the "mundane reality" which he paradoxically seeks to expose its other ugly side.

Roger Caillois draws a basic distinction between fairy tales and the fantastic

... in the fantastic, the supernatural appears as a break with the principle of universal coherence ... the fantastic comes after the fairy tale and practically replaces it ... the fairy tale is set in a world where enchantment is taken for granted ... The fantastic presupposes the solidity of the real world but only to ruin it more radically. (Italics mine, pp. 9-10)

Thus, the police station -as a setting deployed by Salem- could be analyzed within the fantastic paradigm since it deviates from the norm of being a place of interrogation, torture and confinement. It is, on the contrary, portrayed as a gallery or a museum. It functions in opposition to the audience's expectation of any normal police station, a point raised by Mustafa, an ambitious journalist and a friend of the Heliopolis police Superintendent:

Mustafa: Impossible! This cannot be a police station ... if so, what does the museum look like, then?

Superintendent: Oh man .... These are very normal things.

Mustafa: Impossible. This cannot be normal. What do I hear? Is this music?!!

Superintendent: Is it a strange thing to hear music here?

Mustafa: Yes, of course ... this is the last thing I could hear in police station.

Superintendent: Then, what do you expect to hear in a police station?

Mustafa: To hear the yelling of a criminal being beaten ...

Superintendent: Please, don't compliment me.

Do you like my police station?

Mustafa: Like it!! The cell here is thousand times much better than my room in the hotel where I live. Please arrest me and let me sleep in your cell. Can you rent it to me? You'll not change anything, you'll just put a small note:' 10\% Service'.

[He looks at the cell once again] Certainly ... it is a dream: a bed, a basin, a radio, magazines.

Superintendent: And cool air conditioning will be installed so soon. (Italics mine, The Phantoms of New Egypt, p. 9)

"Here", as an index sign, is seen "abnormal", "strange" and dreamy. The irony is that the idealistic Superintendent seeks a better "here" as seen in the use of "still" in conjunction with the use of the future tense "I will". The dialectic relation between the present tense and the future one highlights the structural function of the title which is itself a clef of post-independence Egypt. The title serves primarily to focus attention on the collapse of the "here" which later proves to be a dystopia.

As the dialogue progresses, the audience gets to know that the Superintendent is about to be awarded the "State prize and the Shield of Absolute Security" for having had no crime records in his police station for three years:

\section{Superintendent:}

Don't envy me, Mustafa. There's still an hour to complete three years. At exactly 12 o'clock, I'll announce the passing of three years after the last reported accident. (Italics mine, The Phantoms of New Egypt, p. 12)

The Superintendent's personal philosophy rests on enhancing what he calls the "precautionary security measures" (The Phantoms of New Egypt, p. 12) to reduce the crime rate till it becomes zero. This idealism as usual foreshadows the forthcoming tension which is a dominant feature in the drama of dystopia. That is because the Superintendent's utopia is unreal with no strong pillars to sustain it, therefore, it will be doomed with the appearance of the first crime record before the time is twelve o'clock at night.

In Salem's play, "New Egypt" could be read "in adjacency to a semi-magical world of recognizable reality" (1994, p. 107), to use Gilbert's words. It is post-independence allegory which "contains the capacity to open ... a gateway into the received codes of history, a way of reading the past, and the investment of the present in it, through a liberating process of imaginative reconstruction" (Selmon, 1995, p. 164). The police station is constructed on a theoretical assumption without any genuine study of the harsh socio-political condition. That is why it fades when it confronts a dismal reality. In his attempt to reread history, propagated as a utopia by a newly-born postindependence regime, Salem resorts to magic realism as a "gateway" to undermine this utopia which proves to be dark. He manipulates the fantastic for the harsh realities of post-independence Egypt. Thereby, The Phantoms of New Egypt is not a pure fantasy since Salem does not dramatize a fairy-tale, but he pokes fun at the Superintendent's idealism which urges him to carry out unrealistic measures to create an ideal police station.

The plot acquires a new turn with the appearance of the first crime record reported by Sohair, Professor of Logic, who narrates "a strange story" (The Phantoms of New Egypt, p. 16) as she terms it, that is, the vanishing of 
her husband, Professor of Law at the University of Cairo. She gives a detailed account of the wonderful night she and her husband spent at the cinema. On returning home, she says the following:

Sohair: I was standing beside the wardrobe and he was near the coat-hanger taking off his jacket. At this moment, the electricity went out for a second and when it came back, I didn't find my husband. (The Phantoms of New Egypt, p. 24)

Her words are received with mockery and disbelief:

Sohair: Please sir ... Watch your words. I am not hallucinating or making up stories. I am not crazy. The story happened as I have narrated it. (The Phantoms of New Egypt, p. 26)

Sohair's past narration shocks and interrupts the cheerful present of the Superintendent. She explains that the point is not "how long has my husband been vanished?" because "the important point", she continues," is his way of disappearing- how he has vanished?" (The Phantoms of New Egypt, p. 23). Scene One in Act One ends on a dramatic note:

Superintendent: ... the signals say that the light went out in many different places for a second and when it came back, someone disappeared. (The Phantoms of New Egypt, p. 28)

At this moment, the telephone rings and an unknown voice delivers a direct threat to the Superintendent to abandon his investigation concerning Professor Sohair's report:

The Voice: Abandon this case. You'll achieve nothing.

Do not dare play with us. You're not up to us. (The Phantoms of New Egypt, p. 28)

In a typical expressionistic technique, this recurrent threatening voice is an offstage auditory clef that dominates the entire dramatic events. This offstage clef involves what Elam terms "a triple discursive orientation" (1984, p. 72):

First, there is an orientation to the dramatic universe itself and its individuals, taken as objects of discourse. Second comes the context of utterance as it emerges directly from the dialogue (I-you and here-now of the speech exchange). And the third element is an orientation towards the co-text, i.e. the verbal context of the discourse with its internal semantic and syntactic structure. (Italics mine, 1984, p. 72)

The dramatic universe of The Phantoms of New Egypt is the "strange" event of disappearing which is associated with electricity that goes out at the moment of disappearing. The context of utterance is established through the (I-you) exchange between the Superintendent and the unknown voice on the one hand, and between him and a group of electricity experts on the other. The experts are hired to find out logical reasons behind the technical problems of electricity. As for the co-text, the structure is revealed in a traditional narrative: introduction, a set of complicated events and a dramatic/tragic conclusion.

Mustafa's recurrent use of "impossible" and Professor Sofair's persistent repetition of "am not hallucinating" and " am not crazy" can make The Phantoms of New Egypt's dramatic structure fall into magic realism which disregards the physical laws. It is often an explanation on the inexplicability of the world - physical, political, cultural, interpersonal- in which we live, therefore, the logic of the narrative is the logic of the fantastic. It is Salem's strategy of "destabilization" and the fantastic becomes a foil against which reality takes on startling intensity in order to debunk "New Egypt" in the post-independence era. Thus, Salem's "strange event" crystallizes unknowable possibilities of ordinary experience under pervasively sad socio-political circumstances. This emphasizes the importance of political satire which is a response to a grim reality and is full of deep and convoluted social and political commentary. Magic realism differs from pure fantasy in the sense that it is set in a normal, modern world with authentic descriptions of humans and society. It involves the fusion of the real and the fantastic, or "an amalgamation of realism and fantasy" (Moore, p. 1).

Moreover, Salem's technique of the fantastic arouses the audience's new perceptions and baffles their automatic habitualization through the poetics of "indeterminacy". That is because the Superintendent is now -after the numerous mysterious calls which he receives every now and then- in a state of 'indeterminacy', that is, he has to fill the gaps he will onward face. Salem's play - from the outset- is as enigmatic as a riddle. With meaning left unexplained and opaque, the recurrence of the "strange events", as well as the unknown calls, generate a number of blanks which are meant to achieve 'an estranging style'.

Scene Two is set in the same police station after seven days of the first reported crime and the Superintendent is seen "very exhausted" (Stage direction, p. 29). That is because the number of the wives who have lost their husbands in the same manner as Professor Sohair's is rapidly increasing:

Superintendent: The number of these women is increasing ... at night

they come to me in my dreams ... filling all the streets

of Heliopolis ... many of them ... thousands ... sitting

on the ground silent ...waiting .... with sad eyes. (The Phantoms of New Egypt, p. 30)

As a result, he quickly holds an emergency meeting with the concerned people [an electrical engineer, a physician and a foreign expert of electricity] to solve this crisis and to find out logical reasons for the disappearing of men especially the humorous ones and whose feet size is forty-two: 
The Engineer Al-Enbaby: We examined all the electrical cables in the reported places. And with the aid of Mr. Opetic, the foreign expert, we concluded that all the electrical connectors are in their proper position and there is nothing wrong with the electricity in the places where you claim the light went out.

The whole story is all a lie, an imagination or as superficial as newspaper unless there are phantoms. The electricity is ok 100\%. (The Phantoms of New Egypt, p. 34)

Being a Professor of Logic, Sohair proposes a number of interpretations to figure out why the electricity has gone out

Prof. Sohair: There can be more than one interpretation. Is it a gang that belongs to a foreign country sending a certain ray as a secret weapon to be directed against us?

Dr. Mansy: You mean a radiation that changes the substance to energy and then reconverts it to a substance in a different place.

Prof. Sohair: .... There is another interpretation. It can be a gang from another planet using a type of radiation which we do not know.

Eng. Al-Enbaby: Since it is a gang - as you assume which belongs to a different planet - why do you say it is the responsibility of the Ministry of Electricity. Go and outsmart the phantoms.

(The Phantoms of New Egypt, p. 38)

Again, "impossible" is repeated to enhance the illogicality and the absurdity of the whole situation. Salem juxtaposes a world of realism with that of a fantasy through the use of lighting as rendered in the Superintendent's account of a number of "strange" events. He narrates a number of incidents in which a pilot while landing, the light goes out for a second and when it comes back, the pilot, has vanished. The same has happened to a bus driver and to a famous surgeon. "The custom in our country says there are phantoms", as the Superintendent comments, "What, then, do the people say in your country?" (The Phantoms of New Egypt, p. 39). The foreign expert answers: "impossible, there are no phantoms. There is science. There is nothing called a ray to stop electricity" (The Phantoms of New Egypt, p. 39).

This highlights Tzvetan Todorov's concept of the fantastic which marks a break with the common order of things, an emergence of the inadmissible into the unalterable everyday legality. For Todorov, the fantastic requires the fulfillment of three conditions. First, the text must oblige the reader to consider the world of the characters as a world of living persons and to hesitate between a natural and a supernatural explanation of the events described. Second, this hesitation may also be experienced by the characters and it becomes one of the themes. Third, the reader has to reject allegorical as well as 'poetic' interpretations (1975, p. 25). In Fantasy, The Literature of Subversion (1981), Rosemary Jackson claims that the fantastic "reveals reason and reality to be arbitrary, shifting constructs, and thereby scrutinizes the category of the 'real'. Contradictions surface and are held antinomically in the fantastic text, "as reason is made to confront all that it traditionally refuses to encounter ... what emerges as the basic trope of fantasy is the oxymoron" (p. 21). This can be seen in the following dialogue in which Abdu, the astronomer, appears on stage asking for help because he feels that he will vanish that night:

Superintendent: What do you mean 'I feel'? Talk logically.

Abdu: What has logic to do with my words.

I 'm a very sensitive person and I feel that

I'll disappear today.

Prof. Sohair: Feeling like what. Describe it exactly to me?

Abdu: $\quad$ As one feels hatred, love. It's a very strong feeling, very concrete. As one feels the mightiness of music, the bitterness of defeat. (Italics mine, The Phantoms of New Egypt, p. 46)

The dominant feature is that of "contradiction", that is, the combination of the opposites: love and hatred, triumph and defeat, music and bitterness. In this context, the audience exercises their power of "hesitation" in relation to Abdu's feeling of disappearing. This state of "hesitation" has become a serious theme to be analyzed in a logical manner. What Abdu feels asserts Salem's view of "New Egypt" that is not based on natural or physical laws or objective reality. This emphasizes the fact that irrational ruling diverts humanity from a normal reality, so "impossible events" can happen, even brutal ones.

This is in line with the technique of magic realism which crystallizes "two conflicting perspectives, one based on a rational view of reality and the other on the acceptance of the supernatural as prosaic reality" (Moore, p. 1). 
Salem uses both perspectives in a hyperbolic way to express the political frustration of "New Egypt". This explains why the dictatorial regime arrests humorous men because laughter has the power of liberation as M. Bakhtin argues: laughter "demolishes fear and piety [it is] a vital factor in laying down that prerequisite for fearlessness without which it would be impossible to approach the world realistically" (qtd in Morson et al., 1990, p. 23).

The timing of the mysterious telephone calls asserts the fact that living under a repressive regime means living in a secretive and lawless state. The voice is a signifier of detectiveness as the Superintendent is always seen over watched. This means that Salem offers a view of post-independence Egypt which undergoes a state of terrorism. The Superintendent is haunted by a number of menacing, unknown calls from different places at different times: a call from Assiut and another one from Paris. The aim is to weaken the Superintendent's will. These mysterious calls symbolically refer to the turmoil in post-independence Egypt:

After the 1967 defeat, the regime continued to open its prison gates in the worst of manner. Fear dominated and surrounded people everywhere .... Political organizations resorted to dirty tricks to arrest people. During this turbulent period, some plays were performed using themes and techniques based on symbols and puns ... (Yusuf, p. 43)

The menacing calls in The Phantoms of New Egypt signify the transgression of law owing to the fact that the post-independence regime is based on a lawless system which itself depends on violence to legitimatize its fearful existence.

In addition, this mysterious voice can act as a "hierarchical observation" (Dreyfuse et al., p. 156) - to borrow Foucault's phrase- which functions within the act of being looked over. This explains that control depends on what Foucault terms as "optics of power" (Dreyfuse et al., p. 156). This "hierarchical observation" is a central technique of what Foucault also calls "disciplinary power"9 (Foucault, 1979, p. 26) which anchors on repression, domination and punishment for the disobedience is always close at hands. "Discipline", here, means "a technique not an institution" and it seeks to "make docile" individuals, that is, "it is the specific technique of a power that regards individuals both as objects and as instruments of its exercise" (Foucault, 1979, p. 170) and its aim is to "normalize surveillance" (Foucault, 1979, p. 23).

The shift from a blissful condition to a nightmarish one can be analyzed within Foucault's concept of "effective history" which seeks to put everything in motion" (Italics mine, Foucault, 1977, p. 153). This stands in contrast to the "suprahistorical" (Foucault, 1977, p.153) perspective that seeks to totalize history. Like the Foucauldean genealogist, Salem dissolves the comforting illusion of human existence as well as all the ideals of truth and beauty. Professor Sohair's dramatic presence before twelve o'clock as well as the occurrence of the telephone calls represe nt a moment of "rupture" and "discontinuity". This "rupture" denotes the absence of "fixed essences", finalities and "discontinuous development" (qtd in Dreyfuse et al., p. 106) -to use Foucault's words.

This moment of "rupture" and "discontinuity" is a signifier of the shift from utopia to dystopia. It is a shift which refuses all the forms of determinism or historical teleologies adopted by a dictatorial regime to impose fixed ideologies which only serve their imperial interests. This is dramatically depicted in Salem's stage direction of the police station which has been radically changed in Act Two:

Stage direction: The police station has lost part of its elegant

appearance ... the colored plastic chain is replaced

by an iron real one. Flowers no longer exist and the

station gradually starts to be like any other normal

police station. (Italics mine, The Phantoms of New Egypt, p. 51)

As a result, Heliopolis police station starts to appear normal in the sense that the cells are full of criminals and crimes record registered in the police files, a point raised by the warrant officer, Hussein:

Hussein: [Shouting] ... this thief inside the cell ...

Superintendent: What's wrong with him?

Hussein: He stole the basin and the radio and got them out of

the cell window to one of his mates. The problem is

he denies that the cell used to have these items ....

The crimes have spread fiercely everywhere ... theft,

burglary, arson and pick pocketing ... (The Phantoms of New Egypt, p. 53)

History is, thus, never a progression towards a better human situation, but rather a cycle that does not confirm to any rational end, but rather obeys its own law of recurrence. The Superintendent himself, in the closing scene, vanishes in the same manner of the Professor and Abdu. He is caught somewhere away when he holds a press conference to announce the "truth" behind these mysterious calls. Consequently, the Superintendent's disappearing can be interpreted within Nietzsche's view of history as a story of petty malice, of vicious intentions, of highsounding stories masking the lowest of motives (Nietzsche, 1956, p. 288).

In a word, The Phantoms of New Egypt reveals deep estrangement and abysmal dissatisfaction with all the claims of promised security that have brought nothing but ontological loss. This proves that the utopian discourse has been shunned because ideal systems have turned into nightmares. Hence, the construction of unshackled imagination involves the use of allegory as seen in the use of magic-realism. 


\section{On the Grotesque:}

Abdul-Fadl is an actant of the grotesque with all its incongruous and terrifying nature. Bakhtin's notion of 'grotesque realism' is be very functional to analyze 'degrading humor' to underscore the brutal role played by a ruthless regime whose theory of security is based on physical torture. This, thus, gives a bleak picture of what has gone grotesque in post-independence Egypt.

\section{1. 'Grotesque Realism' Revisited}

The multifarious studies of the grotesque fail to provide a constant definition due to its "jellyfish nature" (Harpham, 1982, p. xv). The pivotal point is to formulate the understanding of the grotesque in close relation to specific historical circumstances and consciousness at a particular time:

Rapid industrialization, unprecedented scientific and technological advances, wars, migration of masses of people, totalitarian regimes, were among the most important although diverse factors responsible for altering people's understanding of the world. (Krzychlkiewicz, p. 9)

The focus of analysis is on the terrifying aspects of what I call post-independence grotesque particularly in "New Egypt".

Generally speaking, the grotesque is defined as "an artistic device", a "mode" of expression, a "tone" for the "entire work" and as it is a departure from the norm, "it is frequently used in satire to expose the immediate and identifiable vices and follies of human beings" (Krzychlkiewicz, pp. 1-2). It is also recognized as " an effect of something distorted, absurd, incongruous, or estranged", when something is presented to us not only as different from what it is, or from what it might be, but is also presented in "a way which does not fit our familiar logical or imaginative power pattern" (Foster, 1966, p. 75). In The Grotesque (1972), Philip Thomson refers to the grotesque in relation to "disharmony", a mixture of both the comic and the terrifying being and "the unresolved clash of incompatibilities" with "the ambivalent nature of the abnormal as presented in the grotesque" (p. 27).

Moreover, Wolfgang Kayser - in his The Grotesque in Art and Literature (1981) - believes that the grotesque world promotes "the awareness" that the "familiar and apparently harmonious world is alienated under the impact of abysmal forces, which break it up and shatter its coherence" (p. 37). In other words, the grotesque is determined by ... the abolition of the law of statics, the loss of identity, the distortion of 'natural' size and shape, the suspension of the category of objects, the destruction of personality and the fragmentation of the historical order. (Italics mine, Kayser, p. 185)

In the play, Professor Abu Al-Fadl is defeated by seemingly incomprehensible phantoms depicted as demonic forces which are responsible for the estrangement of "New Egypt". Herein lies the modern grotesque which is seen as an exceptional monstrosity of horrid ugliness. This enhances the interwoven threads between satire and the grotesque to assert the dystopic condition.

Salem's use of satire foregrounds Bakhtin calls "degrading humor" defined as " a downward movement from the upper to the lower bodily stratum" (Dentith, p. 83). The core function of the grotesque is "not to hide, but to expose" (Mann, 1966, p. 122). Evoking sentiments of revulsion is meant to defamiliarize the world by altering its norms. In Bakhtinian view, laughter can be read as satire to "inspire disgust of fear" (Bakhtin, 1984a, p. 63). This brings to the fore what Bakhtin also terms as "grotesque realism" which will be analyzed within the realm of 'degrading humor'. That is, central to 'grotesque realism' is the principal of 'degradation':" the lowering of all that is high, spiritual, ideal, abstract ... to the material level, to the sphere of earth and body in their indissoluble unity" (Bakhtin, 1984a, pp. 19-20). He also adds the "bodily element" in 'grotesque realism' is viewed as "deeply positive":

... The material bodily principle is contained not in the biological individual, not in the bourgeois ego, but in the people, a people who are continually growing and renewed ... This exaggeration has a positive, assertive character. The leading themes of these images of bodily life are fertility growth, and a brimming-over abundance ... (Bakhtin, 1984a, p. 19)

Bakhtin stresses the Rabelaisian loftiness of eating and drinking in human life and "strives to justify them ideologically ... to erect a culture for them" (Morson, 1990, p. 439). In fact, Bakhtin's exaltation of the bodily emissions - [digestion - urination - defecation - copulation] as evidence of the human form in a constant state of growth and change - represents his utopian Socialist vision.

This utopian vision is dismantled in The Phantoms of New Egypt whose aesthetics are centrally characterized by 'degradation', by a 'downward movement' into the material and 'the bodily element'. 'Degradation' appears in a negative vein, retaining none of those regenerative features of Bakhtin's beliefs. In fact, Salem sees degradation in a traditional way that raises the intellect above the body. Salem allegorizes the brutal role played by the regime to give a bleak picture of which has become so grotesque. Thus, Salem's 'grotesque realism' offers a realistic historic awareness which encounters dehumanization, so fabulous heroes have vanished in both the literal and metaphorical sense.

\subsection{A Grotesque Body in Pain: A Sign-System of the Politics of Coercion}

Salem uses parallel scenes to emphasize the gross abuse of power in post-independence Egypt. The first scene marks the return of the Professor of Law, Abu Al-Fadl who avoids answering all the questions concerning his disappearance. The same happens with Abdu, the astronomer. What arouses the Superintendent's attention is that both men are unable to sit probably because they have "pimples" at their back: 
Abu Al-Fadl: It's my right to have pimples at any time.

Superintendent: I know that the freedom of pimples is a legitimate right to all people. (The Phantoms of New Egypt, p. 67)

The vitality of the Professor's and the Superintendent's dialogue lies in what Elam calls the "context-ofutterance", i.e., (I-you-here-now) since the central [I-you] dialectic is defined by the principle of interchangeability .... [It is] the primary exchange in the drama, from which its tension and dynamic derive" $(1980$, p. 143). The dialogue of both characters is structured on the abuse of the 'felicity conditions' which render the dialogue defective. I mean that the Professor of Law performs a sequence of individual illocutions and the irony is that he is fully aware that his speeches are defective. He abuses the felicity condition of sincerity as he does not say what he believes, thereby, the relation between the signifier and the signified collapses since he avoids logical answers which are supposed to be uttered by a Professor of Law.

On the other hand, the listener recognizes the speaker's illocutionary intentions as rendered in his satiric reply. Austin calls the listener's recognition of the speaker's illocutionary intentions the '"securing of uptake' ... without it, the intended illocution is doomed to failure" (1962, p. 117). On this point, Elam explains the fact that the abuse of the 'felicity condition' is an integral verbal sign in comedy: "Comedy is full of such "infelicities' caused by the nonsecuring of up-take, the result usually being a form of 'talking at cross-purposes' where the interlocutors reciprocally defeat each other's attempts at conversational progress" (1980, p. 164).

These illocutions, therefore, are comic verbal signs of the politics of coercion as adopted by a fearful regime. The bodies of the Professor and the journalist are disfigured because of brutal 'disciplinary' tactics. These disfigured bodies are signs of the aesthetic nature of the grotesque which violently resists concepts of beauty, order and harmony because "pimples" may contain puss which is something unclean and causes feelings of revulsion and has nothing of the regenerative features of Bakhtin's notions of human growth and fertility. In this sense, Kayser ponders that "we smile at the deformations, but are appalled by the horrible elements as such" (1981, p. 31).

Actually, Salem's choice of a Professor of Law and a disreputable journalist -who is only responsible for the marginal parts as the Zodiac and the Cross-word Puzzles - is apt and suggestive. The significant implication is to refer to the haphazard arrest. Not only does the regime arrest political activists or dissenters, the concentrated camps are also directed against all people and against freedom of speech to impose fear and to create 'docile' and brainwashed puppets:

Superintendent: The accidents of disappearing are increasing all over the world ... this causes man to feel panic in every place ... thereby destroying the human civilization ... imagine if all the thinkers disappeared, imagine if all the genius men disappeared ... all the people who have a vision to lead humanity, to build a great civilization disappeared ... (The Phantoms of New Egypt, p. 72)

This is a sign of a terrifying 'grotesque' which is based on a punitive system. This is in opposition to the essential role of the state power whose prime function is to maintain order and security. Salem's parallel scenes are a dramatization of subordination which confirms the existence of an undebated political institution. This random arrest creates a psychological state of "regularity" denoting "a custom" interpreted as "the banality of power" which is defined as "the repetition in everyday actions and gestures within systems of domination" (Mbembe, p. 166). Fear is the worst sensation that can be felt asleep or awake. It is identical to the worst nightmares. Yet, in "New Egypt", it has become "a habituation" to avoid clashes with the regime:

Superintendent: How did you come back?

Abu Al-Fadl: I haven't come yet. Yes, I'm not the same old person. I've left all what was inside me there. (The Phantoms of New Egypt, p. 69)

Superintendent: [Satirically]. They've taken from you all what was inside you and have only left you a pimple.

What a strange gang! (The Phantoms of New Egypt, p. 70)

This dialogue recalls the following words by De Toro:

The contextualization of discourse, in both the dramatic text and in the performance text, is carried out by means of deixis and anaphora that impregnate the speech act. The use of deictics and anaphora is an inherent part of the speech act and its function is very important in the communication of the message and in the determination of the verb tenses. (p. 13)

"There" and "yet" refer to a spatio-temporal deixis which works both by means of time adverbs and verbs. The anaphoric reference to the Professor's "strange event" marks the shift from the iconic deixis to the symbolic one because the deictic workings of theatre discourse are different from every day discourse. This is attributed to the fact that

in the latter the deictic dimension does not need to be inscribed semantically within the verbal fabric of discourse itself, remaining a pure and simple index while in the former, the indexical dimension is semanticized, becomes iconic (being inscribed, with a surplus of information, within the verbal-pragmatic fabric) and becomes symbolic (entering into the paradigmatic axes of a text-action which, far from retaining the fragmentary or 
'spontaneous' character of a collection of everyday utterances, appears as an organic and 'fictitious' structure). (Serpieri et al, pp. 165-166)

"There", therefore, is a symbolic index of a wasteland where man experiences the most fearful physical torture. Throughout the dialogue, the Professor resorts to pauses and silences performing a set of deliberate illocutionary acts. This spot lights on his emotional vulnerability. He resorts to silence as he is quite conscious that he is under ceaseless inspection.

A ceaseless inspection can be analyzed within Foucauldean panoptical system of domination:

Foucault interprets the panoptic prison as an apparatus that not only renders the prisoners pliable, but transforms them. The all-pervasive, normalizing influence of an omnipresent disciplinary power reaches via training the body, in every day behavior and produces the motivation for regulated labor and an ordered life. (Italics mine, Habermas, p. 84)

The main function of the panopticon is to "alter" behavior, to "train" or "normalize" individuals. This is a vital stage in the regime's adoption of "disciplinary power". Both Abu Al-Fadl and Abdu have been subjected to physical punishment. This forces them to "police automatically" their behavior and answer none of the Superintendent's questions. In this context, Foucault claims that the use of "disciplinary power" is so effective because it "induce[s] in the inmates a state of conscious and permanent visibility that assures the automatic functioning of power" (1995, p.201), thereby; "visibility is a trap" (1995, p. 200) set by a merciless regime to curb any opposition.

To appear normal, the Professor of Law inaugurates an Institute for Belly Dancing while Abdu opens an office of hypnosis to practise the art of fortunetelling and to decode the unknown future from the remaining marks in a cup of coffee:

Inevitably, the grotesque confuses or even completely shatters our own value system; what to us is insignificant is presented as significant, what is trivial is awarded recognition, while what we consider holy is placed amidst mundane banality. (Italics mine, Krzychlkiewicz, p. 14)

Belly dancing and hypnotism are signifiers of mere physicality and intellectual coma. This is post-independence Egypt after the 1967 defeat which shattered many values and ideals; therefore, Law has lost its significance and has been converted into belly dancing tunes. When a totalitarian regime deprives people of their inner feeling of safety, it creates fake needs such as the unreasonable eagerness to know the future:

Abdu: [Enthusiastically]. Thank God! My clients are very high,

Sir. Yesterday, three important men from the Ministry

of Planning visited me. I did what made them feel happy

and they left my office satisfied. (The Phantoms of New Egypt, p. 80)

The endeavor to appear normal in an abnormal society is a clear sign of 'mental sickness'. It is a kind of 'adjustment' to provide a fake feeling of peace and security. Abu Al-Fadl creates a make-believe world and Abdu's office of hypnosis is a kind of powerful intoxication to remain unconscious. Both men have lost their personal identity; they have lost the power of reasoning and the capacity for a right choice. They both swallow a large dose of some strong intoxicant to appear normal, hence, undergo a state of "de-individualization". To reduce "human diversity" to "the subhuman uniformity" is the dehumanizing system of a totalitarian regime that forces people to escape from responsibility and morality into a kind of animal mindlessness.

\subsection{The Professor of Law: A Degraded 'Carnivalized Personality'}

The locus of 'degradation' is rendered in the depiction of the Professor of Law, Abu Al-Fadl, within the mode of a "carnivalized personality" (p. 234) as propagated in Bakhtin's Dostoevesky. The Professor's dilemma is that he is involved in a dystopic situation which "places a person in extraordinary positions that expose and provoke him, it connects and makes him collide with other people under unusual and expected conditions ... " (Bahktin, 1984b, p. 105). The Professor's confrontation with his wife marks a radical change in his personality. She is shocked by his decision to give up his academic career and instead run an Institute for Belly Dancing:

Prof. Sohair: Before making a revolution in the conception of the oriental dance ... tell me what is the secret behind your mental metamorphosis. (The Phantoms of New Egypt, p. 84)

His defense seems only logical to him. He justifies his strange action in terms of money:

Abu Al-Fadl: I'll be responsible for their [the belly dancers] advertisements, arrange their concerts and I'll take a very big commission. I can earn 600 per a night ... even in hard currency. (The Phantoms of New Egypt, p. 89)

In another justification, he states that "magazines only publish the photos and the latest news of the famous belly dancers even the news of the retired ones"

Abu Al- Fadl: Show me one magazine cover with the photo of a Professor of Logic. Show me any news about Law. (The Phantoms of New Egypt, p. 90)

Logic and Law are no longer signifiers of reason and justice. They only exist as abstracts without any real or functional effect. Professor Sohair, in her attempt to talk logically to restore him to sanity, replies:

Prof. Sohair: ... Is the whole matter fame and money? Our real concern is to establish civilization. 
Abu Al-Fadl: Not only Law and Logic can establish civilization.

I'll establish another one by my own standard,

by the tune of belly dancing music. Excuse me, I have

to leave. I still have a lot of work to do. I need to

choose the music and design the belly dancing

costumes. (The Phantoms of New Egypt, p. 92)

This dialogue involves a speaker (S1) who produces an act of persuasion, a listener (L1) who should produce a perlocutionary act, i.e., being persuaded and a topic of discourse (T1). If Sohair (S1) succeeds in achieving her aim to dissuade her husband from collapsing his academic career and L1 (the Professor of Law) provides the desired perlocution, the role of grotesque realism will be suspended. It is worth noting that in order for the act of persuasion to be, as J. R. Searle argues, a "happy act", the speaker whether S1 or S2 should be in a position to perform an act of that kind" (Searle, 14). In the present situation, S1 is in a position to perform a happy act as far as she is concerned to keep her marriage alive, yet S2 is in no position to be persuaded since he has become a distorted grotesque image who is not any more fit to be a decent husband to a respectable wife. In terms of 'degradation', he decides to have " a joyful acceptance of the materiality of the body" (Dentith, p. 66) as theorized by Bakhtin. This is dramatically demonstrated in his selection of the belly dancers' photos:

Abdu: This is a divorced dancer. She is fond of belly dancing.

She has a very elastic body.

Abu Al- Fadl: She is a little bit fat. Never mind. While practicing,

we can make this part lose weight and make that part

gain some extra weight.

Abdu: Every part in this dancer's body plays perfectly without music. (The Phantoms of New Egypt, p. 93)

It is a celebration of what is physical at the expense of what is intellectual. He breaks all his connection with Law and instead he cherishes the carnival or celebration of the materiality. As a result, the Professor rejoices in a temporary suspension ${ }^{12}$ of all hierarchic distinctions as exemplified in his new relation with Abdu who greets him "what a musical night" calling him 'Abu Hameed' [the slang nick name of Ahmed]. The Professor's everyday low slang language is distorted too as he asks for cigarettes and beautiful dancers.

Salem's use of 'degrading humor'4 is seen in the drastic change from an interest in Law to an interest in "Mesakaa مسقعة" [a famous and oriental Egyptian food] (The Phantoms of New Egypt, p. 88), the shift from the "head" to the lower parts of human body, from the notions of "national economy" to the "employment of fifty belly dancers to cover the need of the local market as well as that in Europe" (The Phantoms of New Egypt, p. 87) as Abu Al-Fadl puts it. This highlights the dehumanizing role played by a dictatorial regime whose aim is to distort human psyche and create instead mutilated beings:

Prof. Sohair: [In a dismal reaction]. Where have you been, Ahmed?

Where is this place on earth one can go and return void

from within. Where and why? For who's benefit?

Where is this place which seizes people and take from

them their faith .... Why not in light? (The Phantoms of New Egypt, p. 91)

"New Egypt" is associated with darkness where illogical and abnormal tactics are practised. Under a totalitarian regime, physical and cheap satisfaction replaces genuine refined art. Man's innermost life is imprisoned in stereotyped frames which keep him away from any authentic and liberal thinking. This is in line with Thomson's following words in which he states that "the most potent grotesque images" are those in which human being retains all "real characteristics" but is no more than "an empty shell". He also adds that despite being "animated" beings, they are "lifeless". These "lifeless" beings are apt to be "simultaneously comical and eerie" - comical because of their "imperfect" behavior and eerie probably because of the "age-old, deep-rooted fears in man" (p. 35).

The Professor's wholeness is splintered into a "plurality" of persons and he becomes dialogically conscious of his duality. "Consciousness" in Bakhtinian thought refers to a personality which is in a state of dialogism which itself is an enterprise to "visualize and portray personality as another, as someone else's personality" (Bakhtin, 1984b, pp. 12-13). In other words, the "carnivalistic" mode of "consciousness" is "polyphonic" and in the "polyphonic" world, ideas are transformed into "images" of people.

The Professor's moral and physical courage are ideas linked with collapse and degradation, accordingly, he interacts as one image to another not as one person to another. While sleeping, Abu Al-Fadl sees nightmares to the extent that "his body shakes violently and he screams loudly" (The Phantoms of New Egypt, p. 85) as his wife tells him. This is actually the terrified being, the collapsed one which he denies or tries to forget by replacing it with the degraded one when he wakes up. In this context, Bakhtin writes that the "consciousness of self is constantly perceived against the background of other's consciousness ... 'I for myself' against the background of 'I for another" (1984b, p. 207), thus, the person addresses the self as another. As being conscious of his dialogized self, the Professor of Law ends his marital life:

Abu Al-Fadl: Indeed, I'll take everything except the books.

I've no space for books in the Institute ... My

whole life has no room for books any more. (The Phantoms of New Egypt, p. 94) 
Books, as signs of intellect and reason, are juxtaposed to the Dancing Institute to highlight the Professor's inner conflict or "carnivalized personality" (1984b, p. 234) as Bakhtin terms it. Professor Abu Al-Fadl hates his mutilated self-due to the fact that it is imposed upon him by a demonic super force. This is described by Bakhtin as "carnivalisation of passion" (1984b, p. 159) characterized by "ambivalence", namely, an alien self creates in him a peculiar hatred towards his personality as a whole:

Abu Al-Fadl: I used to believe that we're working in the most important fields; Law and Logic. I used to believe that we work together to make our world better .... At last, I've discovered that we should not lecture the students as parrots. The recorder can do the whole job much better than us. At least, it will not feel tired or even grow old. Even if it is broken, it can be repaired with little money. Yet, if a professor is internally broken, he can not be repaired. (The Phantoms of New Egypt, p. 95)

It is not a separation between a man and his wife. Abu Al-Fadl's breakdown of his marriage is a signifier of the separation between Law and Logic whose relation has become pointless in a lawless post-independence Egypt.

Obviously, physical torture is central to the textual/structural pattern of the play which is combined with a dialogized/dehumanized self. Physical torture is responsible for the tense life experienced by the Professor and this results in "inappropriate speeches", that is, all sorts of violations of the generally accepted and "the established norms of behavior" (Bakhtin, 1984b, p. 117). This is the normal outcome of the fear of punishment in "New Egypt". The grotesque quality, therefore, has become a signifier of conflicts and themes of tragedy that tackle human fate, the meaning of existence and the discrepancy between absolute power and human fragility. This pinpoints the mutual relation between the grotesque and tragedy. The only difference is that tragedy brings catharsis, while the grotesque offers no consolation.

In conclusion, the selected play conveys the ambiguities of living under post-independence regimes that are secretive, lawless and repressive. The practices of these lawless regimes are the ugly face that pinpoints the stage of disillusionment as experienced by the Professor of Law. For the dramatist, the very raison d'être of The Phantoms of New Egypt becomes -to use Jameson's term- " a retextualization of Hisory". History, as Jameson rightly argues, is the experience of 'Necessity': "Necessity is the inexorable form of events; it is a narrative category in the enlarged sense of some properly narrative political unconscious which is a retextualization of History. Therefore, drama of disillusion is not merely a historical account of post-independence Egypt, but it is "history which hurts"the nation's sensibility to instigate action the depicted brutal military regime.

\section{Endnotes:}

[1] The current paper is adapted from my PhD. Dissertation entitled, Post-Independence Drama from Utopia to Dystopia in Selected plays by Wole Soyinka and Modern Egyptian Dramatists, submitted to the Department of English Language and Literature, Faculty of Arts, Cairo University, 2010, supervised by Prof. Amal Aly Mazhar, Panel Committee: Prof. Nihad Seleiha and Associate Prof. Naglaa Al-Hadidy.

[2] All the translations rendered in The Phantoms of New Egypt are done by the present researcher.

[3] In Discipline and Punish: The Birth of the Prison (1979), the French archaeologist of 'knowledge', M. Foucault describes the process of 'normalization' through his analysis of Bentham's Panopticon, a 19th century prison system in which the prison cells were arranged around a central watch tower from which the supervisor could watch inmates, yet the inmates could never be certain when they were being watched, therefore, overtime, they began to police their own behavior. The Panopticon has become the metaphor for the processes whereby disciplinary 'technologies' together with the emergence of a normative social science, 'police' both the mind and the body of the modern individual (Dreyfus et al., pp. 143-167).

$$
\begin{aligned}
& \text { 1. . عبده : يا مسا السيكا .... المسائل كلها في الحشوب التمام ... مسا الليل يا مدام. } \\
& \text { (بعض الكلمات التي سيتبادلانها ليست مفهومة و لا تعنى شيئا محددا). }
\end{aligned}
$$

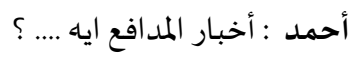

$$
\begin{aligned}
& \text { عبده: أخر تمام ... (يخرج علبة السجائر و يعطيه سيجارة و يشعلها لهـ) } \\
& \text { دي بقى أنقح من بتاعة امبارح. } \\
& \text { الدكتورة سهير (تراقبهما باشمئزاز شـيد) }
\end{aligned}
$$

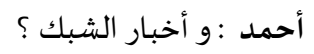

$$
\begin{aligned}
& \text { عبده: غمزت ... (يخرج بعض الصيور الفوتوغرافية ) (عفاريت مصر الجديدة، بـو ). }
\end{aligned}
$$




\section{Bio Information:}

Marwa Essam Eldin Fahmy Al-Khayat is an Associate Professor of Comparative Literature and Criticism at Ahram Canadian University, Egypt. She received her MA (2002) and PhD (2010) degrees in Postcolonial Comparative Drama from the University of Cairo. She published a number of academic articles in international journals and books on Semiotics, Stylistic Interpretations, Animation and Multi-Cultural Children's Literature. She also published a translation of Juha's Anecdotes within the paradigm of Humor and Laughter Theories. Finally, she is a reviewer in many international Canadian and Indian journals as well as a member in Arab Researcher Association in Emirates and International Ecolinguistics Association funded by the University of Gloucestershire.

\section{References:}

[1] Al-Khayat. Marwa, Ali Salem's The Comedy of Oedipus: You're the One Who Killed the Beast (1969)1: A Classical Tragedy Revisited, Bulletin of Advanced English Studies, 3(1) (2019), 44-59, https://doi.org/10.31559/baes2019.3.1.5

[2] Armitt. Lucie., Theorizing the Fantastic, London: Arnold., (1996)

[3] Austin. John., How to Do Things with Words, London: Oxford UP, (1962)

[4] Bakhtin. M. M., The Dialogic Imagination: Four Essays, Austin: Texas UP, (1981)

[5] Bakhtin. M. M., Rabelais and His World. Helen Iswolsky (trans.), Bloomington: Indiana U P, (1984a)

[6] Bakhtin. M. M., Problems of Dostovesky's Poetics. Caryl Emerson (ed. \& trans.), London: University of Minnesota Press, (1984b)

[7] Booker. M. Keith, The Dystopian Impulse in Modern Literature: Fiction as Social Criticism, London: Greenwood Press, PDF e-book, (1994)

[8] Caillois. Roger, Anthologie du Fantastique, Paris: Gallimard, (1966)

[9] Claeys. Gregory, The Cambridge Companion to Utopian Literature, Cambridge: Cambridge University Press, PDF e-book, (2010)

[10] Claeys. Gregory, News from Somewhere: Enhanced Sociability and the Composite Definition of Utopia and Dystopia, History, 98(330) (2013), 145-73.

[11] De Toro. Fernando, Theatre Semiotics: Text and Staging in Modern Theatre, John Lewis (trans.). Frankfurt: Madrid, (1995)

[12] Dentith. Simon, Bakhtinian Thought: An Introductory Reader, London \& New York: Routledge, (1995)

[13] Dreyfus. Hubert L. \& Rabinow. Paul (eds.), Michel Foucault: Beyond Structuralism \& Hermeneutics, Chicago: Chicago University New Press, (1982)

[14] Eagleton. Terry, Literary Theory: An Introduction, London: Basil Blackwell, (1989)

[15] Elam. Keir, The Semiotics of Theatre and Drama, London \& New York: Methuen, (1980)

[16] Foster. Ludmila, The Grotesque:A Method of Analysis. Zagadnienia Rodzajow Literachich Ix (1): 1966. Quoted in "Towards the Understanding of the Modern Grotesque" by Krzychlkiewicz, Agata, Journal of Literary Studies, (2003).

[17] Foucault. Michel, The Order of Things: An Archaeology of Human Sciences, London: Tavistock, (1970)

[18] Foucault. Michel, Discipline and Punishment: The Birth of the Prison, Harmondsworth: Penguin, (1979a)

[19] Foucault. Michel, Power, Truth and Strategy. MeaghanMorris \& Paul Patton (eds.), Sydney: Feral Publications, $(1979 \mathrm{~b})$

[20] Gilbert. Helen, De-scribing Orality'. Describing Empire: Post colonialism and Textuality. Chris Tiffin \& Alan Lawston (eds.), London: Routledge, (1994)

[21] Habermas. Jürgen, Some Questions Concerning the Theory of Power: Foucault Again". Critique and Power: Recasting the Foucault/Habermas Debate. Michael Kelly (ed.), Massachusetts \& London: The MIT Press, (1994) 
[22] Krzychlkiewicz. Agata, Towards the Understanding of the Modern Grotesque, Journal of Literary Studies, 19(2) (2003), 205-228, https://doi.org/10.1080/02564710308530325

[23] Harmpham. Geoffry, On the Grotesque: Strategies of Contradiction in Art \& Literature. Princeton: Princeton University Press, (1982)

[24] Jackson. Rosemary, The Fantasy, the Literature of Subversion, London: Methuen, (1981)

[25] Jameson. F., An Interpretation: Literature as a Socially Symbolic Art". Twentieth Century Literary Theory, K. M. Newton (ed.). London: Macmillan, (1988)

[26] Kayser. Wolfgang, The Grotesque in Art and Literature. U. Weisstein (trans.), New York: Columbia U P, (1981)

[27] Mann, Lurii V., o Grotesque VLiterature.Moska: Sovets, Pisatel, 1966. Quoted in "Towards the Understanding of the Modern Grotesque" by Krzychlkiewicz, Agata. Journal of Literary Studies, (2003)

[28] Mathews. Richard, Fantasy: The Liberation of imagination, New York: Twayne Publishers, (1997)

[29] Mbembe. Achille, Power and Obscenity in the Post-colonial Period, Rethinking Third World Politics. James Manor (ed.). London \& New York: Longman, (1991)

[30] Moore. Lindsay, Magical Realism, (1998), www.english.emory.edu.

[31] Morson. Gary Saul \& Emerson. Caryl, Mikhail Bakhtin: Creation of a Proasaics, stand ford \& California: Stand ford U P, (1990)

[32] Nietzsche. Friedrich, The Birth of Tragedy (1872), Francis Golffing (trans.). New York: Anchor Books, (1956)

[33] Searle. J. R. (ed), The Philosophy of Language, Oxford: Oxford U P, (1971)

[34] Selmon. S., Magic Realism as Postcolonial Discourse, Magical Realism. Horis Parkinson Zamora \& Wendy B. Faris (eds.). London: Duke U P, (1995), pp. 407-426.

[35] Serpieri. Alessandro, Keir Elam. Paolo Gulli Publiatti. Tomaso Kemendy \& Romana Rutelli, Toward a Segmentation of the Dramatic Text, Poetics Today, 2(3) (1981), 163-200, https://doi.org/10.2307/1772470

[36] Thomson. Philip, The Grotesque, London: Methuen, (1972)

[37] Todorov. Tzvetan, The Fantastic: A Structural Approach to a Literary Genre, Richard Howard (trans.). Ithaca, NY; Cornell University Press, (1975)

[38] Zamora. H. P. \& Faris. Wendy B. (eds.), Magical Realism London: Duke U P, (1995)

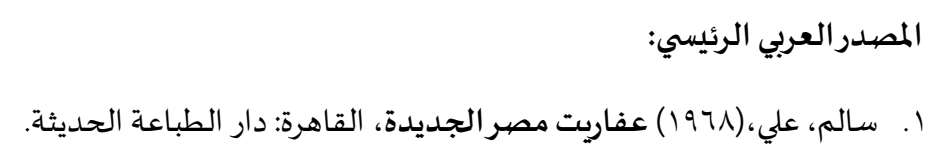

